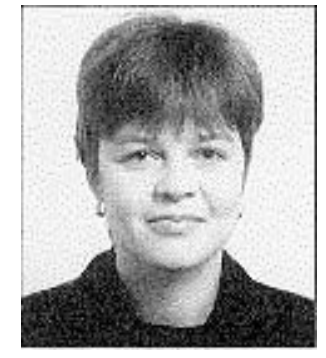

\title{
Aikuiskasvatus ja integroidut koodit: Ohjaava koulutus avoimena aikuispedagogiikkana
}

\author{
Tarkastelen artikkelissani ohjaavan koulutuksen rakentumista \\ sosiaalisena käytäntönä keskittyen toiminnan ja tiedon \\ organisointitapoihin. Käytän hyväkseni Basil Bernsteinin ideaa \\ 'integroivasta koodista'. Termi kuvaa pedagogiikkaa, jossa \\ tietosisältöjen merkitys vähenee, vuorovaikutustapojen keskeisyys \\ kasvaa ja jossa kontrolli ja evaluointi tulevat implisiittisiksi ja \\ diskursiivisemmiksi. (Ks. viite 1)
}

Ohjaava koulutus uutena aikuispedagogiikkana Ohjaava koulutus on työelämään ja koulutukseen sekä urasuunnnitteluun ohjaavaa työvoimapoliittista koulutusta, joka perustuu opiskelijoiden omaan toimintaan, työharjoitteluun ja ohjauksen rooliin oman toiminnan tukena. Ohjaava koulutus toteutuu perinteisten osaamisalueiden rajoilla, ja se toteuttaa muodissa olevia aikuiskoulutuksen ideaaleja: oppijan omaa asiantuntemusta ja aktiivista, kokeilevaa toimintaa opiskeluprosessin lähtökohtana, opetussuunnitelman räätälöintiä sekä kouluttajan roolia prosessin fasilitoijana. Opetussuunnitelmat eivät sisällä sidottuja tietosisältöjä, ja ohjaavaa koulutusta koskeva laatukonsepti ja sen opetussuunnitelmakehys (Onnismaa \& Taskinen, 1994, 1-53; Järvinen ym. 1996) korostavat 'prosessien' ja vuorovaikutuksen luonnetta, eivät spesifejä tiedollisia tavoitteita. Tulos- ten määrittelyssä vältetään sitoutumista nimenomaisiin toivetiloihin kuten työllistymiseen.

Tarkastelen seuraavassa ohjaavan koulutuksen rakentumista Basil Bernsteinin kasvatuksellisen tiedon koodin idean avulla. Erittelen vuorovaikutuksen muotoja, tiedon organisoinnin sekä arvioinnin tapoja ohjaavassa koulutuksessa. Kasvatussosiologi ja sosiolingvisti Bernstein on analysoinut organisoivia periaatteita (koodeja), jotka muokkaavat koulun opetussuunnitelmaa, pedagogiikkaa sekä arviointikäytäntöjä (Bernstein 1977a, 1977b, 1977c). Koodit kuvaavat sitä, miten tarkasteltavassa toiminnassa määritellään, mikä kelpaa tiedoksi, miten tietoa on välitettävä sekä miten tiedon omaksuminen (koulutuksen tulos) tunnistetaan.

Kysymystä koulutuskäytäntöjen rakentumises- 
ta ja rakenteiden uusiutumisesta on käsitelty vähän suomalaisessa aikuiskasvatustutkimuksessa. Aikuiskoulutus nähdään yleensä yksilöiden emansipoijana ja muutosvoimana. Aikuiskoulutuksen muotoja tarkastellaan harvoin esimerkiksi piilofunktioiden tai sosialisaatioprosessien näkökulmasta. Aikuiskoulutusta tarkastellaan yleensä keinona pikemmin kuin instituutiona tai käytäntönä. Käytänkin Bernsteinin ideoita nimenomaan eritelläkseni ohjaavaa koulutusta sosiaalisena käytäntönä. Toiminnan rakenteiden ja tiedon jäsentymisen periaatteiden analysoiminen voi osoittaa tärkeitä aikuiskasvatuksen empiirisen tutkimuksen kohteita.

Bernsteinin kasvatussosiologiassa (emt.) lähtökohtana on kysymys sosiaalisesta järjestyksestä. Opetussuunnitelman tutkimuksen oletetaan paljastavan yhteiskunnan järjestyksen säilyttämisen muotoja. Bernstein tarkastelee kasvatuskoodeja eri maiden peruskouluissa luokitellen opetussuunnitelmia kokoelmatyyppisiin (collection types) ja integroituihin (integrated types). Käsitteet ovat jatkumoita, joiden avulla voidaan kuvata ja vertailla kasvatuskäytäntöjä, vaikka ne eivät sellaisenaan riitä eksaktiin empiiriseen analyysiin. Uskoakseni ne kuvaavat todellisia toimijoiden käyttämiä erotteluja erilaisten toimintatapojen välillä (vrt. Power, 1996, 9-14). (Viite 2)

Kokoelmatyyppinen opetussuunnitelma rakentuu tiedonala- tai oppiaineperustaisesti, ja alojen väliset rajat pidetään verrattain tiukkoina. Integroiduissa koodeissa opetussuunnitelma taas rakentuu jonkin eheyttävän kasvatusperiaatteen varaan, jonka suhteen valittavat sisällöt määrittyvät, ja tiedonalojen rajoja häivytetään. Tämä periaate muodostuu toiminnan keskeiseksi järjestyksen ja mielekkyyden lähteeksi. (Bernstein, 1977b.)

Bernstein tarkentaa typologiaansa vielä kahden käsitteen, luokittelun (classification) ja kehyksen (frame) avulla, joiden kautta hän tarkastelee opetussuunnitelman, pedagogiikan sekä arvioinnin jäsentymistä eri koodeissa. Luokittelulla viitataan koulutuksessa välitettyjen sisältöjen (aineiden) välisiin suhteisiin ja niiden välisen rajanvedon voimakkuuteen. Luokittelu on opetussuunnitelmaa muotouttava ydinperiaate, se kuvaa yhteiskunnassa tärkeitä tiedonalueita ja niiden välisiä rajoja. Kehys taas viittaa pedagogiikkaan, eli kontrollin määrään, joka toimijoilla on opittavan aineksen valikoinnin, rytmittämisen ja ajoittamisen suhteen. Kehys kuvaa myös käytännöllistä rajanvetoa opittavan tiedon ja 'muun tiedon' välillä. (Emt.)

Bernstein kuvaa integroidun koodin toteutumista esikouluikäisten kasvatuksessa näkymättömän pedagogiikan käsitteen avulla (1977c). Siinä (1) opettajan oppilaaseen nähden harjoittama kontrolli on implisiittistä, (2) opettaja järjestää kontekstin, jota oppilaan puolestaan tulee tutkia ja uudelleenjärjestää, (3) oppilaalla on tämän kontekstin puitteissa mahdollisuus organisoida tekemisiään, ajankäyttöään sekä sosiaalisia suhteitaan, (4) spesifien taitojen opettelemista korostetaan vähän, ja (5) arvioinnin kriteerit ovat epämääräisiä ja moniulotteisia. Kuvaus on osuva myös ohjaavan koulutuksen suhteen. Itse asiassa suuri osa aikuispedagogisia tilanteita organisoidaan Suomessa nykyisin juuri näin - nimittäen niitä avoimiksi, itseohjautuvuutta tukeviksi oppimisjärjestelyiksi.

Bernstein esittää, että siirryttäessä kokoelmakoodista kohti integroitua koodia vuorovaikutuksen muodot tulevat formaaleja tietosisältöjä keskeisemmiksi ja kontrollin muodot implisiittiksi ja diffuuseiksi (piileviksi ja epämääräisiksi). Bernsteinin mukaan integroitu koodi merkittävästi muuttaa koulutuksen arviointikriteerejä sekä sosiaalisia suhteita opettajien ja oppilaiden välillä. Bernstein rakentaa ko. käsitteiden pohjalta kehikon, jonka avulla hän vertailee koulukoodeja eri maissa.

Tässä puolestani sovellan ideaa ohjaavan koulutuksen erittelyyn ja osoitan haasteita empiiriselle aikuiskoulutuksen tutkimukselle. Pohdin ohjaavaa koulutusta esimerkkinä käyttäen, mitä tapahtuu opetussuunnitelmalle, pedagogiikalle ja arvioinnille, kun sekä kehys että luokittelu ovat väljiä. Bernsteinin käsitteiden ohella hyödynnän ohjaavaa koulutusta koskevia tekstejä, työko-kemustani ohjaavana kouluttajana 
sekä huomioita ohjauskeskusteluja käsittelevästä tutki-musaineistostani. (Viite 3)

Onnismaa kirjoittaa (Onnismaa \& Taskinen, 1994, 10): 'Ohjaavan koulutuksen lähtökohtana on opiskelijan tilanne. Ero muuhun koulutukseen on siinä, että opiskelija työstää omaa tilannettaan ja minäänsä. Oppijakeskeisyyden ja itseohjautuvuuden ideat ovat siis alun perin olleet itsestäänselvyyksiä'. Ohjaavan koulutuksen opetussuunnitelmakehys kuvaa koulutusta näin: '(O.K.) auttaa työelämän muutosvaiheessa olevia nuoria ja aikuisia löytämään urallaan suunnan. Henkilökohtaisen ja ryhmäohjauksen sekä työharjoittelun ja/tai ammatilliseen koulutukseen tutustumisen avulla osanottajat laativat työmarkkinasuunnitelman. Tavoitteena on sellaisten ajatus- ja toimintamallien tuottaminen, joka auttaa yksilöitä itsenäisiin ratkaisuihin työelämän ja koulutusjärjestelmän muutoksissa’ (Järvinen ym. 1996, 2).

Tässä tiiviissä kuvauksessa tavoite ('auttaa löytämään suunta') on muotoiltu niin, että se mahdollistaa laajan vaihtelun sen suhteen, mitä 'suunta' kulloinkin tarkoittaa. Sisältöjen sijasta kuvataan tarkasti niitä eri vuorovaikutustilanteita, joiden kautta tulos pyritään tuottamaan. Lopuksi viitataan 'itseohjautuvuuden piilo-opetussuunnitelmaan': toimintojen mielekkyyden ei ajatella perustuvan vain siihen konkreettiseen tulokseen (esim. työnsaantiin), jonka ne ehkä saavat aikaan. Niiden varsinainen mielekkyys nähdään siirtovaikutuksessa, 'valmiuksissa', joiden avulla toimia myöhemminkin elämässä. Toisaalta tällainen itseohjautuvuuden yleisihanne voidaan tarvittaessa kutsua esiin oikeuttavana uskomuksena ihmisestä.

Opetussuunnitelma antaa ohjeellisia kuvauksia teema-alueista ja tavoitehierarkioista, jotka koskevat asenteellisia ja viestinnällisiä valmiuksia sekä sitä, kuinka laajasti tarvittaessa liikutaan pelkkien työelämä- ja koulutuskysymysten rajojen yli. Joskus työnhakupreppaus riittää, joskus taas lähes koko elämäntilanne on työn alla. Ohjaava kurssi näyttäytyy yhtäältä resursseina (aikaa, tilaa, ohjausta), toisaalta toimintana (tiedonhankinta, työharjoittelut, työnhakudokumenttien valmistelu, keskustelut) ja lopulta kuvauksina valmiuksista, joita kurssin pitäisi opiskelijoissa kehittää. Korostetaan, että 'koulutuksen laatu saavutetaan erilaisia tiedonhankinnan, opetuksen ja oppimisen menetelmiä käyttämällä eikä nimeämällä sisältöjä’ (emt. 15). Ohjaavan koulutuksen eetoksen voi tiivistää: 'Ohjaavassa koulutuksessa opiskelija on oman tilanteensa paras asiantuntija ja kouluttaja on koulutusprosessin asiantuntija.' (emt. 4). Ohjaavan koulutuksen integroivana ideana voi pitää ajatusta itseohjautuvuudesta sekä ihanteena että kykyinä, joihin opiskelija harjaantuu toimiessaan kurssin suosimien toimintojen mukaisesti.

Erittelen seuraavassa Bernsteinin käsitteiden avulla, mitä koulutuksen keskeisissä viestintäsysteemeissä (opetussuunnitelma, pedagogiikka ja arviointi) tapahtuu, kun kehys ja luokittelu ovat väljiä. Ohjaava koulutus toimii esimerkkinä aikuiskoulutuksen piirissä sovelletusta integroivasta koodista.

\section{I}

Opetussuunnitelma - mikä kelpaa tiedoksi: Ohjaavassa koulutuksessa opiskelijan tarvitsemalle tiedolle ei aseteta varsinaisia kriteereitä. Yksilön tilanteinen tiedon tarvehan katsotaan keskeiseksi toiminnan jäsentäjäksi. Tiedon kriteerien määrittäminen jätetään siis koulutuksen ulkopuolelle: tietoa haetaan sieltä, missä sitä kulloinkin arvellaan olevan. Tämä ei tarkoita, ettei erilaisia käytännön kriteerejä sovelleta jatkuvasti, mutta kyseessä on tällöin ohjaavan kouluttajan henkilökohtainen asiantuntemus, eivät muodolliset oppisisällön kriteerit.

Ideana on tukea eri järjestelyin opiskelijan elämänsuunnittelua ja opettaa opiskelijalle tämän oman toiminnan kautta uusia toimintatapoja. 'Mikä kelpaa tiedoksi' ei tällöin olekaan tärkeä ydinkysymys, vaan: mikä kelpaa relevantiksi toiminnaksi. Luokittelun väljentäminen tarkoittaa tietosisältöjen suhteellistamista: kaikille yhteisesti merkittäviä tietosisältöjä ei ole, vaan tiedon katsotaan rakentuvan subjektiivisesti koetun nojalla. On etsittävä muita kuin tietosisältöihin palautuvia oppi- 
misen tunnusmerkkejä. Ne etsitään vuorovaikutuksen ominaisuuksista.

Kysymys siitä, mikä kelpaa relevantiksi toiminnaksi, ratkotaan periaatteessa räätälöimällä. Käytännössä se ratkeaa usein ennalta suositeltujen toimintavaiheistusten kautta. Ohjaavan koulutuksen opetussuunnitelma esitetään opiskelijoille sekä ostajille erilaisina toiminnan muotoina. Nämä toiminnat esitetään suosituksena; näin valinnanvapaus säilyy. Samalla kuitenkin opiskelijoiden toimintaa koskevan selontekovelvollisuuden peruste muokkautuu esitetyn mallin kautta. Omatoiminen tiedonhankinta, työpaikkojen kokeileminen jne. näyttäytyvät vapaasti valittavina, järkevinä asioina. Opiskelija, joka aikoo tehdä 'jotain muuta', joutuu esittämään toimintansa järkevyyden suhteessa niihin ihanteisiin, jotka oikeuttavat tarjottua mallia: itse tekeminen tehokkaana oppimisen tapana, itsenäinen tiedon hankkiminen ja kokemusten reflektointi.

Tämä on esimerkki implisiittisestä kontrollista, jota syntyy integroiduissa koodeissa muodollisten, eksplisiittisten kontrollimuotojen tilalle (Bernstein, 1977c). Muodolliset pakot tehdä tiettyjä asioita tiettyyn aikaan vähenevät, sen sijaan tietyt toiminnan järkevyyden perustelemisen tavat tulevat tärkeiksi. Opiskelijan näkyvä toiminta voi olla muutakin kuin esim. työharjoittelua, mutta tärkeätä on, että toiminta voidaan tarvittaessa selittää mielekkääksi suhteessa itseohjautuvuuden ideaaliin. Opiskelijaan kohdistuva ulkoinen kontrolli vähenee ja sisäinen kontrolli kasvaa (vrt. Giddens, 1991). Samalla kurssitoimien läpinäkyvyys vähenee. Toimimisen rinnalle vähintään yhtä tärkeäksi tulee toiminnasta puhuminen. Teot eivät sinänsä kanna mitään ilmeisiä pedagogisia merkityksiä, vaan niiden pedagoginen relevanssi (eli merkityksellisyys oppimisen kannalta) on rakennettava yhdessä eri interaktiotilanteissa.

Tärkeä opetussuunnitelmaa koskeva kysymys on ohjaavien kouluttajien osaamisalueen määrittäminen. Ohjaavaa koulutusta voisi kutsua antiprofessionalismin kautta itseään määritteleväksi professioksi. Kouluttajien intressinä on ollut asiantuntemuksensa muotoileminen, halu korostaa oman osaamisen erityisyyttä ja toisaalta sitä, että vältetään perinteisten professioiden ylhäältä annettu asiantuntemus, 'paremmin tietäminen’. Ohjaavan koulutuksen itseymmärryksessä ohjausala nähdään muiden professioiden virheet välttävänä. Tähän kuuluu ajatus toiminnan oppijakeskeisyydestä. Oppija on oman tilanteensa asiantuntija eikä ohjaajalla ole autoritääristä asemaa.

Samalla mm. opetussuunnitelmatyöskentely Opetushallituksen myötävaikutuksella (Järvinen ym. 1996), laatujärjestelmien tuottamat koulutuksen arviointipaineet (Onnismaa, 1997) sekä ohjaavien kouluttajien oma kehittämistyö tuottaa ammatillisia välineitä ja kuvauksia, jotka yhtenäistävät toimintatapoja, tekevät ne helpommin tarjottaviksi, luovat yhteisiä standardeja - ja näin tavallaan 'kohteistavat' asiakkaan. Opiskelija otetaan periaatteessa tasa-arvoiseksi työskentelykumppaniksi, jonka omaa asiantuntemusta arvostetaan. Toisaalta tämä asiantuntemus voidaan kyseenalaistaa työn arjessa. Ohjaava kouluttaja voi vaikkapa joutua tilanteeseen, jossa työharjoittelupaikalta kerrotaan kaksi ristiriitaista versiota jostain tapahtumasta, kurssilaisen ja työnantajan. Ohjaava kouluttaja voi joskus pitää opiskelijan käsityksiä itsestään tai jostain asiasta epärealistisina. Ohjaavan kouluttajan työn arkeen kuuluu miettiä, milloin oma arvio tai mielipide on paikallaan, milloin ei. Haasteena on olla tasaveroinen työkumppani, joka tukee toista käyttämään omaa asiantuntemustaan, ja samalla kuitenkin olla asiantuntevampi professionaali. Halutaan olla 'arjen asiantuntijoita', operoida arkikielellä, mutta samalla välttää ajatus, että kuka hyvänsä osaisi tehdä sen, mitä ohjaava kouluttaja tekee.

Ohjaavan koulutuksen taustalla näkyy siten sekä professionaalistumista että pyrkimystä artikuloida työn erityisluonne professionaalisuuden kritiikin avulla. Ohjaavan koulutuksen ohjausvuorovaikutuksen tarkastelu paljastaa, että samanaikainen pyrkimys yhtäl̈ltä vaikuttaa opiskelijaan ja toisaalta välttää avointa direktiivisyyttä näyttää olevan keskeinen ohja- 
uksen vuorovaikutuskäytäntöjä muotouttava tekijä (vrt. He, 1994; Silverman, 1997, luku 9). 'Ohjauksellisuus' vuorovaikutuksen piirteenä muotoutuu siis juuri näihin pyrkimyksiin suuntautumisen kautta. Se vaikuttaa merkittävästi ohjaajien kysymisen, neuvomisen sekä opiskelijan puheen vastaanottamisen tapoihin. Ammatillisuus, jonka olemusta hahmotetaan välttämisen kuvauksin ('emme tee kuten perinteinen professionaalisuus tekee'), itse asiassa muotouttaa aivan omanlaisiaan ohjauskäytäntöjä. Ne ovat erilaisia kuin teoreettisesti pitkälle mallinnetut, lähinnä psykologiaan pohjautuvat ohjaustekniikat, joissa on taustalla enemmän positiivisia määritelmiä ihmisestä tai psyykestä (viite 4) (vrt. Peräkylä, 1995).

\section{II}

Pedagogiikka - mikä kelpaa tiedon siirtämisen tavaksi: Pedagogiikka tarkoittaa Bernsteinilla kehyksen säätelyä; tapoja, jotka katsotaan soveltuviksi tiedon siirtämiseen sekä näiden tapojen valinnan ja vaihtelun mahdollisuutta.

Ohjaavassa koulutuksessa opetussuunnitelman ja pedagogiikan kysymykset sulautuvat yhteen. Toiminnan järjestykset, vuorovaikutuksen muodot ja tavat tehdä asioita tulevat oleellisemmiksi kuin sisällöt - ne ovat itse asiassa yhtä kuin sisällöt. Tähän viitataan usein puhumalla 'valmiuksista' ja erilaisista 'prosesseista' produktien sijasta. Vuorovaikutuksessa on otettava huomioon yksilöllisiä eroja toimijoiden välillä, mikä tarkoittaa, että on väljennettävä toimintamuotoja ja irrotettava niitä aika-paikka -rajoista.

Vuorovaikutuksen ja erilaisten 'kompetentin aikuisen' valmiuksien korostaminen muuttaa koulutuksen organisointitapoja. Selvimmin näkyvät luokkahuoneen ja aikatauluttamisen hajoaminen ja päätösvallan uudenlainen jakautuminen (vrt. Kauppi, 1995). Ohjaavassa koulutuksessa tärkeinä toimina ovat harjoittelut, tutustumiskäynnit, tiedonhankinta ja keskustelut. Syntyy tilanteita, joita ei ole välttämättä totuttu jäsentämään pedagogisina tilanteina ja joiden tavoitteista osapuolilla ei ole aina selvää kuvaa.
Integroidut koodit luovat itse asiassa uusia vuorovaikutuksen muotoja, jotka ovat empiiriseltä kasvatustutkimukselta vielä haltuun ottamatta. Perinteisen luokkahuonepuheen analyysit $(\mathrm{mm}$. Mehan 1974; McHoul, 1990) eivät tavoita niitä. Esimerkkinä voi mainita $\mathrm{mm}$. yksilöohjauksen yhtäältä tukitoimena, toisaalta kontrollin ja tarkkailun muotona. Ohjauskeskusteluhan on keskeisesti raportointitilanne, jossa opiskelija selostaa tekemisiään ja jossa toimijat yhdessä konstruoivat opiskelijan edistymistä. Juuri näissä tilanteissa opiskelijan toiminnan pedagoginen relevanssi (ts. 'se mitä toimista on saatu irti') tulee kouluttavan instituution kannalta havaittavaksi.

Toinen keskeinen pedagoginen käytäntö on kokemuksista puhuminen ja reflektointi ryhmässä. Ohjaava koulutus ei edellytä juuri yksilöohjausta, mutta kylläkin yleensä keskustelu- ja prosessointimahdollisuuksia. Mm. ryhmäterapiasta (Wootton, 1976), psykodraamasta (Vehviläinen, 1996b) ja keskinäisen avun hoitomuodoista (Mäkelä ym. 1996, 133-152) tuttu ‘jakamisen' (sharing) formaatti voi tulla tällöin merkittäväksi. Jakaminen toimii sekä vuorovaikutusjärjestyksen että 'asialistan' kannalta hyvin eri tavoin kuin opetuskeskustelu tai luento. Jakamisessa kerrotaan monologeiksi jäsentyneissä puheenvuoroissa henkilökohtaisia kokemuksia jostain asiasta. Jokaisella on oikeus tällaisen vuoron esittämiseen ja toisten vuoroja vältetään haastamasta, usein kommentoimastakin. Jakaminen on otollinen tapa arkaluontoisten asioiden käsittelyyn sekä moraalisen yhteisyyden vahvistamiseen.

Kuten sanottua, opiskelijan oman toiminnan raportoiminen on aikuiskoulutuksessa keskeinen pedagoginen käytäntö. Ohjaavassa koulutuksessa erilaiset raportoinnit ovat välttämättömiä paitsi siksi, että suuri osa opiskelijoiden omatoimisista tekemisistä saatetaan siten ohjaavan instituution piiriin, myös siksi, että näille toiminnoille on luotava pedagogisia jäsennyksiä diskursiivisesti, ts. jonkinlaisen keskustelun, neuvottelun, yleensä sosiaalisen merkityksenannon kautta. Mekaaninen toiminta ('tein mitä kuului tehdä’) on erotettava sisäistyneestä, 
'reflektiivisestä' toiminnasta - nimenomaan puhumalla toiminnasta yhdessä. Ohjaavassa koulutuksessa toiminnan sosiaalinen merkitys syntyy useista kerrontatilanteista, joissa omaa toimintaa raportoidaan muille ja kuullaan muiden raportointeja. Vaikka ohjaavan koulutuksen konkreetit tulokset olisivat läpinäkyviä (esim. löytyy työpaikka), on 'itseohjautuvuuden piilo-opetussuunnitelman' toteutuminen aina nimenomaan diskursiivisesti todentuva asia. Läpinäkyvyydellä tarkoitan toimijoiden mahdollisuutta toiminnassaan rutiiniomaisesti tunnistaa jonkin toiminnon tai kokemuksen merkitys ja luottaa, että muut tunnistavat sen suunnilleen samoin. Hyvä koetulos voi olla tässä mielessä läpinäkyvä asia. Sen sijaan työharjoittelukokemus ei sitä välttämättä ole. Jonkin kokemuksen tulkinta vaikkapa 'asioita eteenpäin auttavaksi oppimiskokemukseksi' vaatii enemmän yhteistä merkitystyöskentelyä. Se edellyttää ainakin erilaisia vuorovaikutuksen keinoja raportoida kokemus, ottaa tämä kerronta vastaan sekä etsiä sille pedagogisia merkityksiä. Kouluttavan instituution kannalta ei siis riitä, että opiskelija tekee tiettyjä tekoja, vaan teot on uudelleenprosessoitava diskursiivisesti, ennen kuin ne voidaan tunnistaa pedagogisesti merkityksellisiksi kokemuksiksi.

\section{III}

Evaluaatio - mikä kelpaa osoitukseksi toiminnan onnistumisesta: Bernstein arvelee integroitujen koodien tuottavan arviointiongelmia, koska arviointikriteerit tulevat diffuuseiksi tai epämääräisiksi. Hän pitääkin integroitujen koodien toimimisen edellytyksenä selkeyttä arviointikriteereissä (1977b). Ohjaavaa koulutusta tarkastelemalla voidaan kuitenkin päätyä eri tulkintaan. Diffuusit arviointikriteerit eivät tarkoita totaalista arvioimattomuutta. Tilanteissa, joissa on vaikea saada aikaan läpinäkyviä tuloksia (kuten työllistymistä) ovat diffuusit kriteerit strategisesti edullisempia kuin tarkat, muodolliset kriteerit. Ne ovat korjautuvia ja säilyttävät ohjaavan koulutuksen mielekkyyden vaihtuvissa tilanteissa. Vaikka ei saavutettaisi määrättyjä konkreettisia tuloksia, voidaan tunnistaa monenlaisia muita vaikutuksia. Näitä ovat usein erilaiset asennoitumiseen, itsetuntoon tai -tuntemukseen liittyvät asiat.

Ohjaavan kouluttajan asiantuntijuus perustuu erilaisten arviointi- ja tarkkailuprosessien jatkuvaan hallintaan. Ohjaava kouluttaja näkee ja rakentaa työnsä mielen - eli myös sen tuloksellisuuden - useissa toistuvissa vuorovaikutuskäytännöissä: haastatteluissa, ohjaus- ja ryhmäkeskusteluissa, työharjoittelutapaamisissa, asiantuntijakontakteissa. Näiden käytäntöjen sisältämät mielekkyyden ja tuloksellisuuden kriteerit ovat paikallisia, ei-formaaleja. Niitä olisi vaikea formalisoida siten kuin päätekäyttäytymisen muotoja tai tietostandardeja. Kuvatessaan toimintaansa ohjaavat kouluttajat usein vetoavat intuitioon ja tilanteeseen heittäytymiseen työn oleellisina piirteinä. Koulutuksen muodollistamisen välttäminen onkin nähtävissä strategisesti tarkoituksenmukaisena: tavoitteiden tietty epämääräisyys mahdollistaa maksimaalisen liikkumavaran käytännössä.

Koska ohjaavan koulutuksen opetussuunnitelma ei sisällä tietoja tai taitoja, joita jokaisen ehdottomasti tulisi hallita, ei ole myöskään olemassa eksaktia tulosmittaria. Työvoimahallinnon käyttämä arviointikriteeri (työllisyystilanne kahden kuukauden jälkeen) ei saa kouluttajien suosiota. Bernstein (1977b, 109) ennakoi, että integroitujen koodien piirissä arviointi koskee enemmän opiskelijan ominaisuuksia tai asenteita. Tämä tarkoittanee jonkinlaisen psykologisen asiantuntemuksen korostumista. Kun ohjaavassa koulutuksessa kuitenkin halutaan välttää myös yksilön psyykeen kohdistuva 'paremmin tietäminen', tulee arvioinnin areenaksi ilmeisesti juuri se vuorovaikutus, jossa kokemusten yksilöllinen merkitys ja niiden pedagoginen relevanssi yhdessä rakennetaan. Merkittävä haaste integroituihin koodeihin siirryttäessä on toiminnan rakentuminen keskeisellä tavalla toimijoiden diskursiivisten kompetenssien varaan.

Opiskelijan motivaation ja 'ei-motivaation' tunnistaminen on yksi kurssin tulokseen vaikuttavista asioista. Kurssilta ei heitetä pois, vaikka 
opiskelija epäonnistuisi kurssin tärkeissä toimissa, jos voidaan muuten ajatella hänen 'tosissaan yrittäneen’. Aito yrittäminen tehdään havaittavaksi erityisesti kontaktin pitona, vuorovaikutukseen antautumisena. Mikään nimenomainen teko ei muodostu ehdottomaksi suoriutumisen kriteeriksi. Rajoja tosin on - opiskelijoitahan välistä heitetään kurssilta - mutta ne ovat tilanteisia ja riippuvat suuresti ohjaajan ja opiskelijan välisen suhteen laadusta. Tässäkin näkyy, miten ratkaisevasti opetusjärjestelyjen muutos avoimeen suuntaan asettaa haasteita juuri ohjaajan ja opiskelijan väliselle vuorovaikutukselle ja siinä havaittavaksi tehdyille asioille kuten 'luottamus', 'rehellisyys', 'aito yrittäminen', 'oikea asenne', 'muutos'.

Ongelmana on tietysti myös, mitä tämä tarkoittaa niiden kannalta, joiden diskursiivinen kompetenssi ja kyky ilmentää 'aitoa yrittämistä' tms. on heikko. Bernstein onkin suhtautunut integroivan koodin mahdollisuuksiin skeptisesti, ja todennut sen suosivan keskiluokkaisia oppilaita, joilla on valmiiksi edellytyksiä toimia sen vaatimilla tavoilla (kts. myös Broady, 1991). Bernstein pohtii, millä edellytyksin integroiva koodi voi toimia todellisena pedagogisena vaihtoehtona (1977a, 84; 1977b, 107 110). Erittelen vielä ohjaavaa koulutusta näitä edellytyksiä koskevien Bernsteinin teesien valossa ja kommentoin niitä.

\section{1} Tarvitaan vahva konsensus integroivan idean suhteen ja sen tulee olla hyvin selitettävissä. Tämä idea on järjestystä ja mielekkyyttä luova tekijä, pikemminkin kuin hierarkiset ihmisten väliset suhteet tai tiedonalat. Ohjaavassa koulutuksessa integroivia ideoita ovat itseohjautuvuuden idea, ajatus opiskelijan elämänkokonaisuuden ymmärtämisestä ja kokemusten reflektoinnin tarpeellisuudesta. Edellä selvitin, kuinka itseohjautuvuuden idea on rakennettu ohjaavaan koulutukseen ja sen oikeuttamisen tapoihin.

Ohjaavan koulutuksen voidaan kuitenkin katsoa toimivan myös siksi, että opiskelijalle jää yleensä käteen muutakin kuin se, että hän on edistynyt itseohjautuvuutensa suhteen. Taskus- sa voi olla siisti ansioluettelo, hieman atk-taitoja, kokemuksia uusista työpaikoista ja toimijarooleista, kontaktiverkostoa. Siksi ohjaava koulutus saa myytyä integroivan ideansa monille opiskelijoille ja työvoimahallinnolle: kurssilla voi joka tapauksessa yrittää tehdä jotain konkreettista. Samalla opiskelijat tulevat sitoutuneeksi integroivaan ideaan omalla toiminnallaan. Jos asiat eivät toimi, on vaikea syyttää pedagogiikkaa, kun on itse sen päätoimija! Silti pelkkä itseohjautuvuuden ihanne ilman näitä käytännön anteja tuskin kantaisi pitkälle. Integroivan idean laajaan hyväksymiseen vaikuttaneekin se, että opiskelijat eivät maksa koulutuksesta suuria summia, vaan ovat työttömiä ja sen johdosta usein jonkinlaisissa vaikeuksissa.

\section{2}

Integroivan idean on muodostuttava opettajien sosiaalistumisen perustaksi: Bernstein esittää, että kokoelmakoodissa opettajaksi sosiaalistumisen perustana on aine- ja tiedetaustaan sosiaalistuminen. Sen sijaan integroidun koodin mukaan toimivassa koulussa opettajien on sisäistettävä opetuksen ytimenä toimiva integroiva idea. Sosiaalistumisen perustana on siis pedagogisen periaatteen ja sitä perustelevan ihmiskuvan omaksuminen - melkeinpä tunnustuksellinen yhtenäisyys opetusajattelussa (Bernstein, 1977b).

Katsoisin jo käytännön kokemukseni perusteella, että tällainen yhtenäisyys ihmiskuvan ja vastaavien periaatteiden suhteen ei ole välttämätöntä. Tärkeätä ei ole niinkään, mihin ohjaava kouluttaja uskoo, vaan miten hän toimii. 'Integroivan idean' käsitettä voisikin tarkentaa sen suhteen, miten se on toiminnassa läsnä. Ohjaavassa koulutuksessa ihmiskuvan julkisina aineksina ovat humanistiset periaatteet. Niiden realisointi toiminnassa - ja niiden käyttäminen tarvittaessa myös oikeuttavina selityksinä - ei edellytä tunnustuksellista yhtenäisyyttä kouluttajien ajatusmaailmojen kesken. Sen sijaan se edellyttää integroivan idean havaittavaksi tekemistä erilaisten vuorovaikutustapojen kautta. Integroivan idean eheys - eli pedagogiikan toimivuus - on löydettävissä itse toiminnan rakentumisen tavoista, ei niinkään ohjaajien aja- 
tusmallien yhteinäisyydestä. Aikuiskoulutuksen tutkimuksenkin pitäisi suuntautua itse toiminnan rakentumisen analysoimiseen pelkkien käsitysten tai ajatusmallien erittelyn sijasta.

\section{3}

Integroivan idean suhde niihin sisältöihin, joita kulloinkin valitaan käsiteltäväksi, on selvitettävä systemaattisesti: Avoin tarjotin edellyttää opiskelijalta käsityksiä siitä, mikä on tärkeää, mikä turhaa. Opiskelijoilla ei aina ole näitä käsityksiä, ja koska opiskelutilanteita on järjestettävä myös ryhmää varten, tärkeän ja turhan välistä eroa joudutaan usein yhdessä ratkomaan. Kuten sanottua, kehyksen väljyyttä rajaa käytännössä tietty käsikirjoitus, toimintojen ketju, joka tarjotaan kurssin jäsentäjäksi. Sen nimenomaiset kohteet ja ympäristöt jätetään opiskelijan päätettäväksi, ja samalla niiden tarkoituksenmukaisuuden arvioiminen muuttuu opiskelijan selontekovelvollisuudeksi tekemisistään. Tämä opiskelijan harjoittama sisäinen kontrolli tulee näkyväksi usein nimenomaan ohjauskeskustelussa. Opiskelijan 'sisäinen' selontekovelvoite saa 'ulkoisen', vuorovaikutteisen muodon selonteoissa ohjaavalle kouluttajalle. Kouluttajasta voi tulla kuin 'omantunnon ääni'. Tämä näkyykin useissa ohjausnauhoitteissa: orientoidutaan selontekovelvollisuuteen ohjaajalle, selitetään ja puolustellaan hänelle miksei ole saatu aikaiseksi tms. Tätä juuri tarkoitan sillä, että yksilöohjaus on paitsi oppimisen todeksipuhumista, myös kontrolli- tai tarkkailutila. Tämä onkin välttämätöntä, koska ohjaavassa pedagogiikassa fyysisesti yhteinen tarkkailutila (luokkahuone) ja yhteiset kontrollimuodot (esimerkiksi kokeet) on purettu.

On mahdollista, että avoimissa käytännöissä tulee vastaan tilanteita, jossa tietyn toiminnon tarpeellisuus kyseenalaistetaan. 'Mitäs tekemistä tällä on urasuunnittelun kanssa?' Ohjausaineiston ja työkokemuksenikin nojalla voin mainita keinoja, joilla tätä relevanssin ongelmaa käsitellään.

Voidaan vedota käytännön ehtoihin ja velvoittaa kurssilainen hyväksymään ne: kun on mon- ta ihmistä ja halutaan ottaa toiveita huomioon, mukaan mahtuu aina niitä, joita juuri tämä asia ei kiinnosta. Toiseksi voidaan vedota mahdollisuuteen olla osallistumatta tilanteisiin, jotka eivät kiinnosta. Lisäksi huonojen kokemusten merkitys voidaan tulkita hyödyllisyydeksi, koska huonoistakin kokemuksista voi oppia (viite 5). Voidaan myös normalisoida ongelma: ongelmallisena esitetty asia tulkitaan osaksi tapahtumien luonnollista kulkua. Integroiva idea on uhattuna silloin, kun opetusta kritisoidaan relevanssin suhteen. Valittamisen käsittelykeinojen on tällöin kyettävä palauttamaan integroivan idean arvo (vrt. Heritage, 1984, 209-212).

\section{$\triangle$ Opettajien ja opiskelijoiden on muodos- tettava erilaisia 'tarkkailevia ryhmiä' toi-} minnan kontrolloimiseksi: Integroiduissa koodeissa arvioimisen perusteet muuttuvat, ja arviointi tulee tilanteiseksi ja diskursiivisemmaksi. Myös arvioinnin subjekti muuttuu. Ohjaavassa koulutuksessa ratkaisu on, että päätösvaltaa on jätetty suoraan opiskelijoille. Toiminta järjestetään niin, että vastuun pakeneminen haittaa eniten opiskelijaa itseään (viite 6).

Yksilöllinen ohjaus on tärkein ohjaavan koulutuksen kontrollin ja arvioinnin muoto. Opiskelija on tavallaan selontekovelvollinen ohjaajalle. Integroivien koodien äärimuodoissa kontrolli ja arviointi lähenevät toisiaan samaan tapaan kuin opetussuunnitelma ja pedagogiikka. Oppimisen sisältö tulee kuvattaviksi viime kädessä vuorovaikutuksen muotojen kautta, ja toiminnan järjestyksen säilyttämisen tavat (1. kontrolli) sekä toiminnan onnistumisen arvioinnin tavat ovat yhteenkietoutuneita. Ohjaus osana pedagogiikkaa on esimerkki tästä: toiminta, joka tukee ja luo mielekkyyttä, samalla tarkkailee tuloksellisuutta.

\section{Integroivien koodien mukaan toimittaes- sa tarvitaan selkeät arvioinnin kriteerit:} Bernstein olettaa, että integroitu koodi tuottaa paitsi epämääräistä arviointia, myös oppilaan asenteiden ja käyttäytymisen altistumista arvioinnille. Ohjaavassa koulutuksessa kuitenkin pyritään välttämään arvioinnin kohdistamista 
opiskelijan persoonaan. Tämä on välttämätöntä jo siksi, että ohjaavat kouluttajat eivät useinkaan ole psykologeja. Ohjaava kouluttaja silti arvioi opiskelijaa ja tämän toimintaa. Dilemmana on edellä mainittu 'anti-professionaalisuuden' kautta muotoiltu professionaalisuus, ja sitä ratkotaan seuraavilla vuorovaikutuksen keinoilla, joita ohjauskeskus-teluista löytyy.

Opiskelijan toimintaa voidaan arvioida tavalla, joka pitää arvioinnin perusteet opiskelijan ulottuvilla, eli vältetään 'piilo-agendan' käyttämistä. Tieto, jota opiskelijan arvioimiseen käytetään, on (periaatteessa) myös opiskelijan itsensä ulottuvilla. Hänen toimiaan arvioidaan suhteessa hänen itse lausumiinsa toiveisiin, hänen aikaisempaan toimintaansa, ja joskus myös ulkopuoliseen, legitiimiksi katsottuun auktoriteettiin, jonka näkemykset voidaan avoimesti asettaa opiskelijan näkemyksiä vastaan. Tällainen asiantuntija on usein työharjoittelupaikan edustaja. Toinen tapa arvioivan puheen toteuttamiseen avointa direktiivisyyttä välttäen on kysyvien puheenvuorojen käyttäminen kritiikin esittämiseen. Niissä saadaan opiskelija itse sanomaan ääneen varsinainen kritiikki. Samalla välitetään ohjaajan näkemys opiskelijalle epäsuorasti, antamatta avointa negatiivista arviota.

Opiskelijan 'asennoitumisen' tai valmiuksien kehittymisen toteaminen tulee erityisen tärkeäksi, kun kurssin konkreetit suoritukset puuttuvat. Kurssin tuloksina pidettäviä avaintapahtumia ostajan näkökulmasta ovat koulutukseen tai työhön meno tai muu tapa, jolla työtön siirtyy pois työttömyydestä tai passiivisuudesta. Jos näin ei käy, on todettava ja näytettävä hyötyä saadun jollain muulla tavalla.

Nämä toiminnot, joissa saatetaan näkyville kurssin oppimisvaikutusta, voivat tuottaa myös omanlaisiaan vastarinnan muotoja, kuten Bernstein (1977c) on ennakoinut (kts. myös Broady, 1991, 162-167; Ziehe 1991, 200-220). Ohjausaineistossani tätä näkyy eniten joidenkin nuorten kurssilaisten yksilöohjauksessa: haluttomuutta tai kyvyttömyyttä osallistua aktiivisesti keskusteluihin, joissa opiskelijan tekemi- sille yritetään rakentaa pedagogisia merkityksiä. Broady (1991) varoittaa implisiittisen, persoonaan ulottuvan arvioinnin mahdollisesta vahingollisuudesta ja yksityisyyden alueiden kapenemisesta ns. edistyksellisissä pedagogiikoissa. Aikuiskoulutuksessa tätä on tuskin lainkaan nähty pohtimisen arvoisena asiana. Aikuiskoulutuksen uusia muotoja tulisi tarkastella myös vallan ja vastarinnan kenttänä.

\section{Lopuksi}

Integroidun koodin riski on tuottaa tilanteita, joissa kaikilta osapuolilta puuttuu 'ajan, paikan ja tavoitteen tuntu' (vrt. Bernstein, 1977a, 84). Bernstein luonnehtii: 'integroidut koodit vaativat paljon suurempia kykyjä luoda synteesejä ja analogioita sekä kykyä sietää epävarmuutta ja nauttia siitä' (1977b, 108). Ohjaavan koulutuksen arki onkin sekä raskasta että antoisaa juuri siksi, että se vaatii jatkuvaa orientoitumista tilanteiseen merkitysten luomiseen ennalta määrätyn, formaalin sijasta.

On ilmeistä, että avoimet pedagogiset järjestelyt tuovat mukanaan paitsi epämääräisyyttä ja -järjestystä, myös uusia, muotoutuvia järjestyksiä ja legitimointitapoja. Nämä valikoinnin, arvioinnin ja tarkkailun diskursiiviset käytännöt, joissa toimijat yhdessä rakentavat toimintansa mielekkyyden paikallisten kriteerien ja paikallisten todistusaineistojen nojalla, ovat aikuiskoulutuksen tutkimukselle ajankohtaisia empiirisiä tarttumakohtia.

Olen esittänyt, että ohjaavassa koulutuksessa oppisisällön kysymykset on muutettu ratkaisevasti vuorovaikutuksen kysymyksiksi. Toiminnan arviointi ja kontrolli kietoutuu samoihin vuorovaikutustilanteisiin, joissa pedagogiikka toteutuu, ja kontrolli ja kuri on pikemmin implisiittistä kuin eksplisiittistä. Toiminnan arviointi siirtyy lähemmäs yksilön persoonaa ja asenteita, tullen näin riippuvaisemmaksi yksilöiden diskursiivisesta kyvyistä. Tässä piilee myös ongelmia, joita tulisi tutkia diskursiivisen vallankäytön näkökulmasta.

Lisäksi ohjaavassa koulutuksessa elää tutkimi- 
sen arvoisia pedagogisia käytäntöjä, joista mainitsin ohjauskeskustelun, ryhmässä jakamisen sekä yleensä toiminnan raportointitilanteet. Avoimessa pedagogiikassa kaikki keskeistoiminnot (selektio, pedagogiikka, arviointi) näyttävät tulevan entistä riippuvaisemmiksi toimijoiden diskursiivisista kompetensseista, eli ne rakentuvat kielellisen esittämisen ja vuorovaikutuskykyjen varaan.

Ajatus oppijoiden emansipoimisesta on aikuiskasvatustutkimuksessa kulkenut rinnan asiantuntijuuden uudelleenmäärittelyn kanssa. Koulutuksen formaalisuuden (muodollisten tietosisältöjen, muodollisten sosiaalisten suhteiden) purkaminen on nähty niin tärkeäksi, että on unohdettu tutkia, millaisia uusia järjestyksen, vaikuttamisen ja vallan muotoja syntyy. Vallankäyttö, järjestys ja sosiaalistumisen tavat muuttavat muotoaan siirryttäessä kokoelmakoodista integroituun, 'perinteisestä' 'edistykselliseen' pedagogiikkaan. Koulutus sisältää aina rakenteellisia vaatimuksia, vaikuttamisen ja kontrollin muotoja, joihin toimijat joutuvat orientoitumaan. Kuten Broady toteaa (1991, 133): 'Jokaisella pedagogisella käytännöllä on oma piilo-opetussuunnitelmansa, myös edistyksellisellä pedagogiikalla.' Koulutuskäytäntöjen ja tiedon organisointitapojen rakenteellinen analyysi on siksi jatkuvasti tarpeellista aikuiskasvatuksessa.

\section{Vittes}

1. Artikkeli on muokattu aiemman englanninkielisen artikkelini pohjalta (Vehviläinen, 1996a).

2. Sally Power (1996) on soveltanut Bernsteinin ideaa integroiduista ja kokoelmakoodeista tutkimuksessaan pastoral care -oppiaineen asemasta englantilaisessa peruskoulussa. 'Pastoral care' on sisällöltään oppilaiden yksilöllisyyttä tukeva oppiaine ja tukimuoto, jonka tavoitteena on oppilaan kokonaisvaltaisen kasvun edistäminen. Aineen sisältöalueet ja työskentelytavat muistuttavat kovasti ohjaavan koulutuksen teema-alueita ja toimintamuotoja.
3. Teen keskustelunanalyyttistä väitöskirjaa ohjaavan koulutuksen yksilöohjausvuorovaikutuksesta. Analysoin ohjauksen keskeisiä rakenteita ja käytäntöjä hetki hetkeltä etenevässä vuorovaikutuksessa opiskelijan ja ohjaavan kouluttajan välillä.

4. Positiivisilla määritelmillä viittaan kuvauksiin, joissa sanotaan mitä toiminnassa pitää tehdä, sen sijaan että sanotaan, mitä halutaan välttää. Termit 'positiivinen' ja 'negatiivinen' eivät tässä sisällä mitään arvolatausta.

5. Tämä ohjausaineistossanikin esiintyvä periaate on elävä sovellus kokemuksellisen oppimisen ideasta: tärkeintä kokemuksessa ei ole sen sisältö sinänsä, vaan oppijan responssi kokemukseen.

6. Poikkeuksena tästä on ns. yhteistoiminnallinen oppiminen, jossa toiminta tarkoituksella organisoidaan niin, että toimijat ovat riippuvaisia toistensa työpanoksesta.

\section{Kirjollisus}

BERNSTEIN, B. (1977a) On the curriculum. Open schools - open society. In Class, Codes and Control, Vol 3. London: Routledge and Kegan Paul

BERNSTEIN, B. (1977b) On the classification and framing on educational knowledge. In Class, Codes and Control, Vol 3.

BERNSTEIN, B. (1977c) Class and pedagogics: visible and invisible. In Class, Codes and Control, Vol 3.

BROADY, D. (1991) Piilo-opetussuunnitelma. Mihin koulussa opitaan. Tampere: Vastapaino.

GIDDENS, A. (1991) Modernity and Self-identity. Cambridge: Polity Press.

HE, A. (1994) Withbolding Academic Advice: Institutional Context and Discourse Practice. Discourse Processes 18, 297-316.

HERITAGE, J. (1984) Garfinkel and Ethnomethodology. Cambridge: Polity Press.

JÄRVINEN, P. \& KATAJISTO, J. \& KELLBERG, A. \& ONNISMAA, J.(1996) Ohjaavan koulutuksen opetussuunnitelman laatiminen. Opetushallitus. 
KAUPPI, A. ym. (toim.) (1995) Adult Education in a Cultural Context. Adult and Continuing Education Research in Finland. Adult Education Research Society in Finland/University of Helsinki, Lahti Research and Training Centre.

McHOUL, A. W. (1990) The organization of repair in classroom talk. Language in Society, 19, 349-377.

MEHAN, H. (1974) Learning lessons. Harvard University Press.

MÄKELÄ, K. ym. (1996) Alcoholics Anonymous as a Mutual-Help Movement. A Study in Eight Societies. Madison: The University of Wisconsin Press.

ONNISMAA, J. (1997) Objaavan koulutukesen laatu ja vaikuttavuus. Objaus- ja neuvontatyön instituutioitumisen tarkastelua. Julkaisematon lisensiaatintutkimus, Helsingin yliopisto, Kasvatustieteen laitos.

ONNISMAA, J. \& TASKINEN, L. (1994) Objaavan koulutuksen arviointia. Rajankäyntiä aikuisopetuksen, sosiaalityön, lybytterapian ja kuntoutuken kesken. Opetushallitus.

PERÄKYLÄ, A. (1995) AIDS counselling. Institutional interaction and clinical practice. Cam- bridge: Cambrdige University Press.

POWER, S. (1996) The Pastoral and the Academic. Conflict and Contradiction in the Curriculum. Cassell Studies in Pastoral Care and Personal and Social Education. London: Cassell.

SILVERMAN, D. (1997) Discourses of Counselling. HIV Counselling as Social Interaction. London: Sage.

VEHVILÄINEN, S. (1996a) Adult education and 'Integrated codes'. The case of Finnish career orientation training. Teoksessa: Adult Education and the Labour Market III, University of Roskilde. Publications from ESREA.

VEHVILÄINEN, S. (1996b) Psykodraaman vuorovaikutuksen rakentuminen. Etnometodologinen tarkastelu.

WOOTTON, A. (1976) Sharing: notes on the organization of talk in a therapeutic community. Sociology 11: 333-350.

ZIEHE, T. (1991) Uusi nuoriso. Epätavanomaisen oppimisen puolustus. Tampere: Vastapaino.

Artikkeli saapui 4.3.1997. Se hyväksyttiin julkaistavaksi toimituskunnan kokouksessa 22.8. 1997. 